\title{
Explorative Study of Entrepreneurship Learning in (STKIP) PGRI West Sumatera
}

\author{
Yeni Erita \\ STKIP PGRI West Sumatera, Indonesia
}

Copyright $(2017$ by authors, all rights reserved. Authors agree that this article remains permanently open access under the terms of the Creative Commons Attribution License 4.0 International License

\begin{abstract}
Entrepreneurship learning is very important at University. The purpose of this learning is to build students' character in entrepreneurship. This research was conducted in qualitative and quantitative to see thirteen characteristics of entrepreneurship. Those characteristics of entrepreneurship in this research produced three groups. The first group was very good category consisted of two items (enthusiastic and ambitious). The second group was good consisted of four items (dare to take an action, uneasy to give up, ethical standard business and independent group). The third group was adequate which was consisted of seven items (resistant to fear of failure, creative and innovative, optimist, patient and diligent, honest, carefree environment, and sensitive to market demand).
\end{abstract}

Keywords Learning, Entrepreneurship, Characteristic

\section{Introduction}

The purpose of education basically is to develop potential capacity of the people and improve their quality of life. Therefore, the people should have an education-starting from primary up to the higher level-pursue a prosperous and better future. The university as the higher level of education provides students with the knowledge that they need in their life. It was supported by the government by signing the Students Entrepreneurs Program of Ministry of Educational and Cultural Affair in 2009. This program is adopted by state university and certain private university. The Entrepreneurship centre organizes this program by providing the students with the knowledge, skill, and entrepreneurship based on science and technology. Thus, the students mindset would be switched from job seeker to job creator and become a entrepreneur who are able to face the global market. This program also encourages others unit in every university to support the entrepreneur program which is stated in the Educational Regulation (UU No.12) of the Higher Educational Goal 2012 that The Education is aimed to create a people who are faithful to God the
Almighty, healthy, knowledgeable, creative, independent, skillful, competitive, and cultured for national prosperity. In accordance to that purpose, the college students have to take the general education program that one of them is entrepreneurships.

Entrepreneurship is a learning subject that aims to build entrepreneur character or provides knowledge about business both in hard skill and soft skill, so the students can take any opportunity surround them and create a job after taking this subject (Santoso, 2013:ii). The idea that lies behind this program is :(1) INPRES (President Instruction) no: 4 on 1995 about the national movement in socializing and familiarizing the entrepreneurships.(2) SKB Ministry of national Cooperation No:02/SKB/Meneg/VI/2000 and No: $4 / \mathrm{U} / \mathrm{SKB} / 2000$ on 29 June 2000. (3) UU No. 12 on 2012 about compulsory subject including entrepreneurship subject. (4) and the regulation of the Presidents of Indonesian Republic No. 27 on 2013 about developing entrepreneurship incubator.

Those regulation and decision are taken to face the challenge of global market; to overcome the problem of the unemployed rate of educated people which considerably very high. Based on national statistical bureau (august 2010), $24.7 \%$ of unemployed are those who have diploma and bachelor degree. Thus, this data becomes the basic consideration to increase the result of studying entrepreneurship in university and to provide the knowledge and skill of entrepreneurship to students in state and private university-including STKIP PGRI Sumatera Barat. The entrepreneurship subject is given in the class, labor and field study to create and build the students' entrepreneurship. It is believed that there are several characters of entrepreneur that should be created in order to be able to survive in global market. Therefore, entrepreneurship learning should provide knowledge and skill to students so they have the character as a successful entrepreneur in the future. Therefore, it is very important to find out whether the entrepreneur learning todays has stimulated students entrepreneurship spirit or not.

There were some related researches on entrepreneurship learning the first is 'In pursuit of a new 'enterprise' and 
'entrepreneurship' paradigm for learning: creative destruction, new values, new ways of doing things and new combinations of knowledge' which was conducted by Allan Gibb (2002). The other research toward the entrepreneurship learning was conducted by Tine A. Jensen (2013) entitled 'A holistic person perspective in measuring entrepreneurship education impact - Social entrepreneurship education at the Humanities. The research of Gibb (2002) studied about the values of entrepreneurship in students perspectives; whether their creative and innovative ideas is creates something meaningful or not, and the knowledge that need to be provided to students. Jensen (2013) studied the impact of entrepreneurship learning to students as the future entrepreneur and to the development of their humanities aspect.

Even though both researches discuss about the entrepreneurship learning, they do not discuss the role or the important of entrepreneurship learning to students' character building. Therefore, this research focused on the characters which are shape up as the influence or impact of the entrepreneur learning.

The research was conducted in STKIP PGRI SUMBAR. The purposes of the research are to find out; 1) whether the implementation of entrepreneurial learning can shape students' entrepreneurial spirit or not and, 2) the obstacles faced by students in entrepreneurship learning.

\section{Review of Literature}

\subsection{Entrepreneurship}

Entrepreneurship is not only defined as the skill in business but also a creative and innovative sense which means dare to take a decision. Some theories related to the definition of entrepreneurships are proposed by Zimmerer (2005), Ciputra (2009), Kasmir (2011) and Amar (2012). Zimmerman (2005) and Kasmir (2011) have the same opinion in defining entrepreneurship that is a process of applying the creative and innovative idea to solve the problem and to find a chance in order to improve the business. Moreover, it is an accumulation of several proper choices to make the dream comes true. Therefore, entrepreneurship is classify as a philosophy of life and work or life foundation in building the careers and achieving success.

Considering the importance of entrepreneurship in shaping the students' character and knowledge to prepare them to compete in the world, it becomes one of compulsory subject. According to Amar (2012), Entrepreneurship learning is one way to adjust the output of education with the market demand and it can raise students' entrepreneurship instinct to survive in the world. Ciputra (2009) and Hendro (2011) admit that entrepreneurship is consistent with Indonesian character; creative, innovative and brave to face the challenge. In addition, entrepreneurship has changed its meaning from offering the benefits in a form of information to using the information as business opportunities. The people who have entrepreneurship instinct has a vision to take advantage of the changing needs, wants, and expectations of the people around him (like merchants, families, the rate of economic growth, revenue, agriculture, social growth, and others).

\subsection{Theories Underlying Entrepreneurship}

There are some theories underlying the entrepreneurship; economy, psychology and attitude. But in this case the economic theory applied is in the micro level rather than in the macro level. The theory of economic is one of basic grip in carrying out the process of entrepreneurial learning in an educational institution, because basically the study of how the people achieve the success and prosperity in their business is discussed in economics. According to Suherman (2008), "to achieve prosperity or real welfare needs cooperation, because to achieve the conditions require variety of sources: land or natural resources, human resources and financial resources. The entrepreneurship learning motivates students to work cooperatively and collaboratively with others to build and develop their business and at the same time encourage them to be independent in managing the business. Therefore the teachers not only have to provide the knowledge and skill of entrepreneurship but also encourage students to work cooperatively and think positively.

The entrepreneurs should prepare themselves with the knowledge of how to see the chance and the market demand, translate it into the business plan and continuously make an innovation. They should not scare to take a risk to manage and develop their business. To overcome his fear, the entrepreneurship successful also has the actual ability, namely: a. Strategic concept, b. Skill (selling, communication, negotiation, leadership, and personality), c. Tactic, d. Motivator, e. Control (finance, cash flow, cost, flow, and etc.) (Suherman, 2008). Suherman also states that to be able to manage the business the entrepreneur should be smart enough to see the business opportunity, credibility, creativity, persistence or the ability to take a risk. However, those knowledge and skills will not work well if the entrepreneur cannot to catch the phenomenon in society which can be used to make an innovation so the business can develop and survive in global market. As stated by Tilaar (2012) that the entrepreneur should be able to see the society's need and have an innovative idea to fulfill it.To maximize the utilization of innovative and creative thinking, the people need to be supported by the quality of social institutions in the community. Schools and educational programs can accommodate the inspiration and the desire to improve their standard living.

The theory of psychology is one of basic knowledge of entrepreneurial learning in educational institutions. This theory is certainly very relevant to planting the qualities which is needed to create an entrepreneur because 
entrepreneurship is an ideal traits that can be used to conduct business (Syamsurias developed by Suherman, 2008). The study of social psychology shows that the successful people is determined by the role of science $18 \%$ and $82 \%$ is on emotional skills, soft skills etc.

According to Elfindri (2010) soft-skill is a life skills, both for themselves, group or society even to God. It is the skill to connect with other people (interpersonal skills), the skills to manage themselves (intrapersonal skills) and the ability to develop the quality of life should work optimally. This means that with these skills the entrepreneur can establish their business and the small entrepreneurial activity can encourage the individual potential (at the micro scale). In macro scale that entrepreneurial activity which is systematized in education will give a great impact to the business world.

On the other hand, Wibowo (2011) says a person who is associated with entrepreneurship should practice much because it can increase individual soft-skill individual. Soft-skill, in the context of education, often distinguished with hard-skill. Hard-skill, in this case, is often identified by the ability/skill or capabilities which are gained from learning in a particular field of science.

\section{Research Questions}

Based on the discussion towards the entrepreneurship, the government regulation towards it and the need to develop entrepreneurship learning model, the research questions are formulated as follows:

1. Can the implementation of entrepreneurial learning create the entrepreneurial spirit of students of STKIP PGRI SUMBAR?

2. What are learning obstacles faced by students of STKIP PGRI SUMBAR in entrepreneurial learning?

\section{Method}

This research used descriptive design in quantitative and qualitative approach. Quantitative approach was used to analyze the characteristics of entrepreneurship learning while qualitative was used to describe the characteristics of entrepreneurship learning.

The population of this research was 300 students of STKIP PGRI SUMBAR at the 2013/2014 Academic year. Then the sample was taken by using simple random sampling where $30 \%$ sample was taken out of the population or 90 students.

The instrument of this research was questionnaire which was used to find out the response from students and lecturer. The instrument was design by first deciding the indicators to find out the character of entrepreneur as shows in the table below:

\begin{tabular}{|c|c|}
\hline Variable & Sub Variable \\
\hline \multirow{4}{*}{$\begin{array}{c}\text { The characters of } \\
\text { Entrepreneurship Learning }\end{array}$} & Enthusiastic \\
\cline { 2 - 2 } & Resistant to fear of failure \\
\cline { 2 - 2 } & Creative and innovative \\
\cline { 2 - 2 } & Dare to take an action \\
\cline { 2 - 2 } & Optimism \\
\cline { 2 - 2 } & Patient, diligent, consistent \\
\cline { 2 - 2 } & Ambitious, uneasy to give up \\
\cline { 2 - 2 } & Uneasy to give up \\
\cline { 2 - 2 } & Honest \\
\cline { 2 - 2 } & Ethical standard business \\
\cline { 2 - 2 } & Sensitive to market demand \\
\cline { 2 - 2 } & Environmental carefree \\
\hline
\end{tabular}

\section{Data Analysis}

The effectiveness of entrepreneurship learning was measured from the result of pre-test and post-test to find out the improvement of students' knowledge before and after learning entrepreneurship. It was also measured by observing students' engagement in classroom learning of entrepreneurship and how they implement their knowledge outside the class. The formula which was used to calculate the percentage of effectiveness data was modified from Riduan's formula (2011:89):

$$
\mathrm{P}=\frac{\text { Jumlahskor }}{\text { Jumlah skor ideal }} \times 100 \%
$$

The effectiveness was also measured from reliability of the instruments using SPSS formula as follows:

1. Alpha Cronbach $\alpha \frac{n}{n-1}\left(1-\frac{\sum \sigma i x^{2}}{\sigma T^{2}}\right)$

2. Intra-class Correlation Coefficient ICC $=\frac{\sigma_{s}^{2}}{\sigma \frac{2}{s}+\sigma_{0}^{2}} \overline{-\sigma_{e}^{2}}$

To find out students' mastery on theory and practice of entrepreneurship learning, the interpretation was conducted by using the criteria; poor $(0 \%-20 \%)$, not good $(21 \%$ $40 \%)$, adequate $(40 \%-60 \%)$, good $(61 \%-80 \%)$, and very $\operatorname{good}(81 \%-100 \%)$.

\section{Finding and Discussion}

\subsection{Finding}

The data of the characteristics of entrepreneurship learning was collected from the questionnaire which was given to 90 students. The data was also taken from the implementation of each characteristics of entrepreneurship learning.

\section{a. Enthusiastic}

This characteristic was applied thoroughly and has the average score 4.1 with $82.04 \mathrm{TCR}$ is in the category of very good as shown in the table below. 
Table 1. The Respondent Data Distribution in Implementing Enthusiastic

\begin{tabular}{|c|c|c|c|c|c|c|c|c|c|c|c|c|c|c|}
\hline \multicolumn{15}{|c|}{ ITEM SEMANGAT } \\
\hline & \multirow{3}{*}{ Pernyataan } & \multicolumn{10}{|c|}{ PILIHAN } & \multirow{3}{*}{\begin{tabular}{|c|} 
Skor \\
Rata-rata \\
\end{tabular}} & \multirow[t]{3}{*}{ TCR } & \multirow[t]{3}{*}{ Kniteria } \\
\hline \multirow[t]{2}{*}{ NO } & & \multicolumn{2}{|c|}{ Selalu } & \multicolumn{2}{|c|}{ Sering } & \multicolumn{2}{|c|}{ Jarang } & \multicolumn{2}{|c|}{ Kadang-kadang } & \multicolumn{2}{|c|}{ Tidak Pernah } & & & \\
\hline & & $\mathrm{f}$ & $\%$ & $\mathrm{f}$ & $\%$ & $\mathrm{f}$ & $\%$ & $\mathrm{f}$ & $\%$ & $f$ & $\%$ & & & \\
\hline 1 & $\begin{array}{l}\text { Dalam pembelaiaran kewirausahaan, dosen mend orong mewuiudkan } \\
\text { ide usaha }\end{array}$ & 31 & 34,44 & 47 & 52,22 & 9 & 10 & 3 & 3,33 & 0 & 0 & 4,16 & 83,2 & Sangat Baik \\
\hline 2 & $\begin{array}{l}\text { Dalam pembelajaran kewirausahaan, dosen menganalisis pilihan usaha yang } \\
\text { us aha yang dikemukakan mahasiswa }\end{array}$ & 24 & 26,67 & 45 & 50 & 19 & 21,11 & 2 & 2,22 & 0 & 0 & 4 & 80 & BAIK \\
\hline 3 & $\begin{array}{l}\text { Dalam pembelajaran kewirausahaan, dosen memberikan keyakinan tepat sang } \\
\text { tindakan tepat sangat penting }\end{array}$ & 21 & 23,33 & 37 & 41,11 & 26 & 28,89 & 5 & 5,56 & 1 & 1,11 & 3,78 & 75,6 & BAIK \\
\hline 4 & \begin{tabular}{|l|} 
Dalam pembelaiaran kewirausahaan, dosen memberikan keyakinan \\
melakukan segala sesuatu secara cepat sanagt penting
\end{tabular} & 15 & 16,67 & 39 & 43,33 & 24 & 26,67 & 8 & 8,89 & 3 & 3,33 & 4,39 & 87,8 & Sangat Baik \\
\hline 5 & $\begin{array}{l}\text { Dalam pembelaiaran kewirausahaan, dosen men anamkan sikap mandiri } \\
\text { mandiri dalam membangun usaha }\end{array}$ & 33 & 36,67 & 41 & 45,56 & 16 & 17,78 & 0 & 0 & 0 & 0 & 4,18 & 83,6 & Sangat Baik \\
\hline & & & & & & & & & & & & 4,1 & 82,04 & Sangat Baik \\
\hline
\end{tabular}

Source: Primary data on 2014

Table 2. The Respondent Data Distribution in Implementing Resistant to Fear of Failure

\begin{tabular}{|c|c|c|c|c|c|c|c|c|c|c|c|c|c|c|}
\hline \multicolumn{15}{|c|}{ Tidak Takut Gagal } \\
\hline \multirow{3}{*}{ NO } & \multirow{3}{*}{ Pernyataan } & \multicolumn{10}{|c|}{ PILIHAN } & \multirow{3}{*}{\begin{tabular}{l|} 
Skor \\
Rata-rata
\end{tabular}} & \multirow[t]{3}{*}{ TCR } & \multirow[t]{3}{*}{ Kriteria } \\
\hline & & \multicolumn{2}{|c|}{ Selalu } & \multicolumn{2}{|c|}{ Sering } & \multicolumn{2}{|c|}{ Jarang } & \multicolumn{2}{|c|}{ Kadang-kadang } & \multicolumn{2}{|c|}{ Tidak Pernah } & & & \\
\hline & & $\mathrm{f}$ & $\%$ & $\mathrm{f}$ & $\%$ & $\mathrm{f}$ & $\%$ & $\mathrm{f}$ & $\%$ & $\mathrm{f}$ & $\%$ & & & \\
\hline 1 & $\begin{array}{l}\text { Dalam pembelajaran kewirausahaan, dosen mend orong mahasiswa da- } \\
\text { lam menciptakan ide kewirausahaan }\end{array}$ & 1 & 1,11 & 26 & 28,89 & 38 & 42,22 & 21 & 23,33 & 4 & 4,44 & 2,96 & 59,2 & CUKUP \\
\hline 2 & $\begin{array}{l}\text { Dalam pembelajaran kewirausahaan, dosen memotivasi mahasiswa } \\
\text { untuk berhasil. }\end{array}$ & 12 & 13,33 & 24 & 26,67 & 14 & 15,56 & 26 & 28,89 & 14 & 15,56 & 2,9 & 58 & CUKUP \\
\hline 3 & \begin{tabular}{|l} 
Dalam pembelajaran kewirausahaan, dosen membentuk sikap \\
mahasiswa dalam mengambil suatu keputusan usaha.
\end{tabular} & 3 & 3,33 & 26 & 28,89 & 41 & 45,56 & 16 & 17,78 & 4 & 4,44 & 3,06 & 61,2 & BAIK \\
\hline 4 & $\begin{array}{l}\text { Dalam pembelajaran kewirausahaan, dosen memberikan keyakinan } \\
\text { tindakan cepat sangat penting }\end{array}$ & 1 & 1,11 & 30 & 33,33 & 34 & 37,78 & 17 & 18,89 & 8 & 8,89 & 2,98 & 59,6 & CUKUP \\
\hline & & & & & & & & & & & & 2,97 & 59,5 & CUKUP \\
\hline
\end{tabular}

Source: Primary Data on 2014

Table 1 shows the average score of each item under the characteristic of enthusiastic. The first item that the lecturer encourages students to create a business, the TCR $83.2 \%$ average score 4.16 is in very good category. The lowest average score was 3.7 with TCR 75.6 for the item; the lecturer builds students confident that the precise action is very important. The highest score is in the item; the lecturer builds students confident that it is necessary to take action at immediate time where the average score is 4.39 with TCR $87.8 \%$ or very good. In conclusion, the enthusiastic as one of the character of entrepreneur is necessary in creating and managing a business. If the entrepreneur has no spirit in business he/she will not achieve a satisfied result.

\section{b. Resistant to fear of failure}

The implementation of resistant to fear of failure as one of the characteristics of entrepreneurship is presented in table 2 .

The total score of the item resistant to fear of failure is 2.97 with TCR $59.5 \%$ which is classified as adequate. It means in learning entrepreneurship, the lecturer should support and motivate the students in starting and running their business. The lecturer should also encourage the students to stand up and try several times if they failed in doing their business.

\section{c. Creative and Innovative}

The characteristic of entrepreneurship in creative and innovative is in adequate category that the average score is 3.06 with TCR $60.5 \%$. It shows that the high priority should be given to inspirational motivation so students' creative and innovative idea will emerge while creating and building a business. 
Table 3. The Respondent Distribution Data in Implementing Creative and Innovative

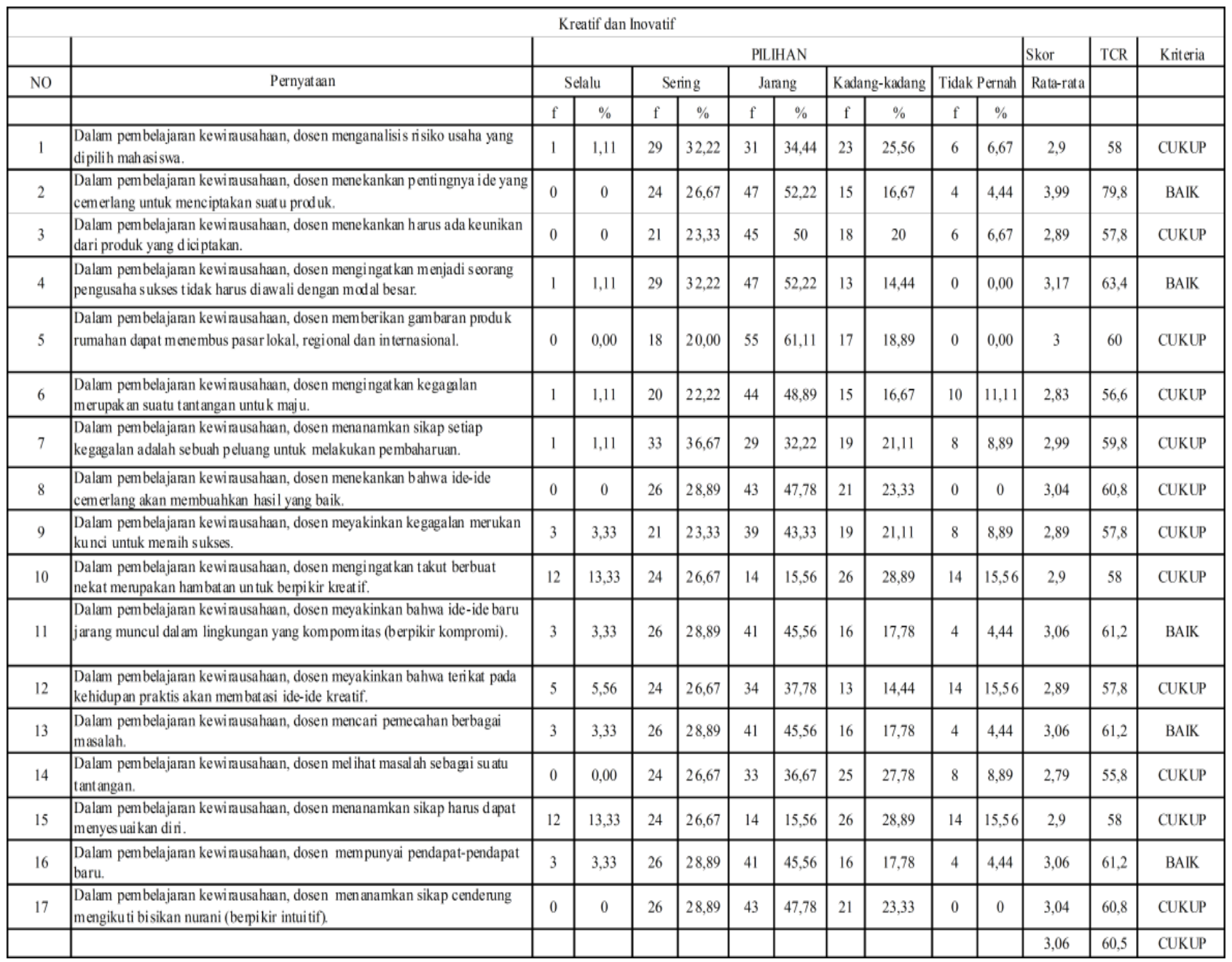

Source: Primary Data on 2014

The data show that the students have creative and innovative idea on the paper indicated by the fact that they had not started their business on the second meeting of entrepreneur learning so the risk taking was not severe enough. The creative and innovative idea of the students of STKIP PGRI Sumatera Barat is in adequate category which needs to be cultivated more in learning entrepreneurship. So they can create and develop a new business or field of job and become financially independent people.

\section{d. Dare to Take an Action}

The implementation of dare to take an action in entrepreneurship learning is in good criteria that the average score is 3.73 with TCR $68.94 \%$. It shows that the students are brave enough to build the business but need to improve their knowledge about banking and technology. 
Table 4. The Respondent Distribution Data of in Implementing Dare to Take an Action

\begin{tabular}{|c|c|c|c|c|c|c|c|c|c|c|c|c|c|c|}
\hline \multicolumn{15}{|c|}{ Bertindak } \\
\hline \multirow{3}{*}{ NO } & \multirow{3}{*}{ Pernyataan } & \multicolumn{10}{|c|}{ PILIHAN } & \multirow{3}{*}{\begin{tabular}{|l|} 
Skor \\
Rata-rata \\
\end{tabular}} & \multirow{3}{*}{ TCR } & \multirow[t]{3}{*}{ Kniteria } \\
\hline & & \multicolumn{2}{|c|}{ Selalu } & \multicolumn{2}{|c|}{ Sering } & \multicolumn{2}{|c|}{ Jarang } & \multicolumn{2}{|c|}{ Kadang-kadang } & \multicolumn{2}{|c|}{ Tidak Pernah } & & & \\
\hline & & f & $\%$ & f & $\%$ & f & $\%$ & f & $\%$ & f & $\%$ & & & \\
\hline 1 & $\begin{array}{l}\text { Dalam pembelajaran kewirausahaan, dosen menekankan pentingnya } \\
\text { kehidupan pribadi terhadap kemajuan ide u saha. }\end{array}$ & 3 & 3,33 & 31 & 34,44 & 37 & 41,11 & 19 & 21,11 & 0 & 0,00 & 3,53 & 70,6 & BAIK \\
\hline 2 & $\begin{array}{l}\text { Dalam pembelajaran kewirausahaan, dosen memberikan pilihan dalam } \\
\text { pemecahan masalah yang dihadapi mah asiswa. }\end{array}$ & 22 & 24,44 & 41 & 45,56 & 19 & 21,11 & 7 & 7,78 & 1 & 1,11 & 3,87 & 77,4 & BAIK \\
\hline 3 & $\begin{array}{l}\text { Dalam pembelajaran kewirausahaan, dosen menanamkan kejujuran dalam } \\
\text { usaha. }\end{array}$ & 36 & 40,00 & 34 & 37,78 & 17 & 18,89 & 2 & 2,22 & 1 & 1,11 & 4,16 & 83,2 & Sangat Baik \\
\hline 4 & $\begin{array}{l}\text { Dalam pembelajaran kewirausahaan, dosen menanamkan disiplin dalam } \\
\text { menjalani usaha. }\end{array}$ & 27 & 30,00 & 47 & 52,22 & 14 & 15,56 & 2 & 2,22 & 0 & 0,00 & 4,08 & 81,6 & Sangat Baik \\
\hline 5 & $\begin{array}{l}\text { Dalam pembelajaran kewirausahaan, dosen memberikan pen getahuan ten tang } \\
\text { pentingnya perencanaan dalam mendirikan suatu usaha. }\end{array}$ & 31 & 34,44 & 49 & 54,44 & 10 & 11,11 & 0 & 0,00 & 0 & 0,00 & 4,22 & 84,4 & Sangat Baik \\
\hline 6 & $\begin{array}{l}\text { Dalam pembelajaran kewirausahaan, dosen memberikan pen getahuan ten tang } \\
\text { akses perbankan. }\end{array}$ & 5 & 5,56 & 24 & 26,67 & 34 & 37,78 & 13 & 14,44 & 14 & 15,56 & 2,89 & 57,8 & CUKUP \\
\hline 7 & $\begin{array}{l}\text { Dalam pembelajaran kewirausahaan, dosen memberikan pengetahuan ten tang } \\
\text { akses pas ar. }\end{array}$ & 22 & 24,44 & 33 & 36,67 & 22 & 24,44 & 9 & 10,00 & 4 & 4,44 & 3,65 & 73 & BAIK \\
\hline 8 & $\begin{array}{l}\text { Dalam pembelajaran kewirausahaan, dosen memberikan keterampilan dalam } \\
\text { menguasai teknologi. }\end{array}$ & 0 & 0,00 & 24 & 26,67 & 33 & 36,67 & 25 & 27,78 & 8 & 8,89 & 2,79 & 55,8 & CUKUP \\
\hline 9 & $\begin{array}{l}\text { Dalam pembelajaran kewirausahaan, dosen memberikan keyakinan } \\
\text { melakukan segala sesu atu secara tepat sangat pen ting. }\end{array}$ & 19 & 21,11 & 46 & 51,11 & 17 & 18,89 & 7 & 7,78 & 1 & 1,11 & 3,81 & 76,2 & BAIK \\
\hline 10 & $\begin{array}{l}\text { Dalam pembelajaran kewirausahaan, dosen memberikan keyakinan } \\
\text { mengimplementasikan usaha dengan komitmen total. }\end{array}$ & 19 & 21,11 & 48 & 53,33 & 16 & 17,78 & 6 & 6,67 & 1 & 1,11 & 3,85 & 77 & BAIK \\
\hline 11 & $\begin{array}{l}\text { Dalam pembelajaran kewirausahaan, dosen memberikan keyakinan jangan } \\
\text { menyerah saat mengalami kesulitan. }\end{array}$ & 34 & 37,78 & 36 & 40,00 & 15 & 16,67 & 3 & 3,33 & 2 & 2,22 & 4,06 & 81,2 & Sangat Baik \\
\hline 12 & $\begin{array}{l}\text { Dalam pembelajaran kewirausahaan, dosen men anamkan dedikasi secara } \\
\text { menyel unuh terhadap us aha yang dilak ukan mahasiswa. }\end{array}$ & 24 & 26,67 & 42 & 46,67 & 19 & 21,11 & 3 & 3,33 & 2 & 2,22 & 3,9 & 78 & BAIK \\
\hline & & & & & & & & & & & & 3,73 & 68,94 & BAIK \\
\hline
\end{tabular}

Source: Primary Data on 2014

The table shows that the lowest of average score of dare to take an action is in adequate category or 3.73 with TCR $68.94 \%$. The lowest score is 2.79 with TCR $55.8 \%$ in adequate category for the item; providing the technological skill. The highest score is 4.22 with TCR $84,4 \%$ and is classified as very good in giving the knowledge of planning in starting and building up the business.

\section{e. Optimistic}

Table 5. The Respondent Distribution Data in Implementing Optimism

\begin{tabular}{|c|c|c|c|c|c|c|c|c|c|c|c|c|c|c|}
\hline \multicolumn{15}{|c|}{ Optimis } \\
\hline \multirow{3}{*}{ NO } & & \multicolumn{10}{|c|}{ PILIHAN } & \multirow{3}{*}{$\begin{array}{l}\text { Skor } \\
\text { Rata-rata }\end{array}$} & \multirow[t]{3}{*}{ TCR } & \multirow[t]{3}{*}{ Kriteria } \\
\hline & \multirow[t]{2}{*}{ Pernyataan } & \multicolumn{2}{|c|}{ Selalu } & \multicolumn{2}{|c|}{ Sering } & \multicolumn{2}{|c|}{ Jarang } & \multicolumn{2}{|c|}{ Kadang-kadang } & \multicolumn{2}{|c|}{ Tidak Pernah } & & & \\
\hline & & $\mathrm{f}$ & $\%$ & $\mathrm{f}$ & $\%$ & $\mathrm{f}$ & $\%$ & $\mathrm{f}$ & $\%$ & $\mathrm{f}$ & $\%$ & & & \\
\hline 1 & $\begin{array}{l}\text { Dalam pembelajaran kewirausahaan, dosen mem berikan pemahaman } \\
\text { perencanaan usaha. }\end{array}$ & 0 & 0 & 26 & 28,89 & 43 & 47,78 & 21 & 23,33 & 0 & 0 & 3,04 & 60,8 & BAIK \\
\hline 2 & $\begin{array}{l}\text { Dalam pembelajaran kewirausahaan, dosen memberikan keterampilan } \\
\text { tentang pembukuan keuangan. }\end{array}$ & 3 & 3,33 & 21 & 23,33 & 39 & 43,33 & 19 & 21,11 & 8 & 8,89 & 2,89 & 57,8 & CUKUP \\
\hline & & & & & & & & & & & & 2,965 & 59,3 & CUKUP \\
\hline
\end{tabular}

Source: Primary Data on 2014

The implementation of optimistic in entrepreneurship learning is considerably adequate that the average score is 2.96 with TCR $59.3 \%$. During the teaching and learning process the students showed their optimistic to starting to do their business but it should be improved because the optimism is important to run the business.

The table shows that from 90 students the average score for item the lecturer gives knowledge to planning the business is 3.04 with TCR $60.8 \%$ and categorized as good. The average score for item the lecturer gives the skill in accounting is 2.96 with TCR $57.8 \%$ and categorized as adequate. The data shows that the optimist character should be strengthened in teaching and learning process so the students are encouraged to create and develop their business. Thus, constructivism approach in learning entrepreneurships has to be done so that the students have an experience in creating, doing and developing their business directly. 


\section{f. Patient, Diligent and Consistent}

The patient, diligent and consistent characters of entrepreneur is in adequate category with the average score $2.94 \%$ and TCR 58.83\%. It means, these items should be improved so the students can keep on moving and fighting in doing their business.

Table 6. The Respondent Distribution Data in Implementing Patient, Diligent and Consistent

\begin{tabular}{|c|c|c|c|c|c|c|c|c|c|c|c|c|c|c|}
\hline \multicolumn{15}{|c|}{ Sabar, Ulet dan tekun } \\
\hline \multirow{3}{*}{ NO } & \multirow{3}{*}{ Pernyataan } & \multicolumn{10}{|c|}{ PILIHAN } & \multirow{3}{*}{\begin{tabular}{|l|} 
Skor \\
Rata-rata \\
\end{tabular}} & \multirow{3}{*}{\begin{tabular}{|l|} 
TCR \\
\\
\end{tabular}} & \multirow[t]{3}{*}{ Kriteria } \\
\hline & & \multicolumn{2}{|c|}{ Selalu } & \multicolumn{2}{|c|}{ Sering } & \multicolumn{2}{|c|}{ Jarang } & \multicolumn{2}{|c|}{ Kadang-kadang } & \multicolumn{2}{|c|}{ Tidak Pernah } & & & \\
\hline & & f & $\%$ & $\mathrm{f}$ & $\%$ & f & $\%$ & f & $\%$ & f & $\%$ & & & \\
\hline 1 & $\begin{array}{l}\text { Dalam pembelajaran kewirausahaan, dosen menanamkan sifat kritis dalam } \\
\text { berbagai usaha. }\end{array}$ & 1 & 1,11 & 33 & 36,67 & 29 & 32,22 & 19 & 21,11 & 8 & 8,89 & 2,99 & 59,8 & CUKUP \\
\hline 2 & $\begin{array}{l}\text { Dalam pembelajaran kewirausahaan, dosen memberikan solusi dari } \\
\text { permas alahan dalam suatu usaha. }\end{array}$ & 1 & 1,11 & 33 & 36,67 & 29 & 32,22 & 19 & 21,11 & 8 & 8,89 & 2,99 & 59,8 & CUKUP \\
\hline 3 & $\begin{array}{l}\text { Dalam pembelajaran kewirausahaan, dosen menanamkan sikap tenang } \\
\text { menghadapi cobaan dal am suatu usaha. }\end{array}$ & 0 & 0 & 26 & 28,89 & 43 & 47,78 & 21 & 23,33 & 0 & 0 & 3,04 & 60,8 & CUKUP \\
\hline 4 & $\begin{array}{l}\text { Dalam pembelajaran kewirausahaan, dosen menanamkan sikap percaya diri } \\
\text { bila produk kita diremehkan oleh orang lain. }\end{array}$ & 4 & 4,44 & 21 & 23,33 & 38 & 42,22 & 19 & 21,11 & 8 & 8,89 & 2,91 & 57,2 & CUKUP \\
\hline 5 & \begin{tabular}{|l} 
Dalam pembelajaran kewirausahaan, dosen menanamkan sikap kompetitif \\
jangan dianggap sebagai momok yang men akutkan.
\end{tabular} & 12 & 13,33 & 24 & 26,67 & 14 & 15,56 & 26 & 28,89 & 14 & 15,56 & 2,9 & 58 & CUKUP \\
\hline 6 & \begin{tabular}{|l} 
Dalam pembelajaran kewirausahaan, dosen menanamkan prinsip \\
menghindari ketergantungan dari para pemangku kepentingan
\end{tabular} & 3 & 3,33 & 26 & 28,89 & 41 & 45,56 & 16 & 17,78 & 4 & 4,44 & 3,06 & 61,2 & BAIK \\
\hline 7 & $\begin{array}{l}\text { Dalam pembelajaran kewirausahaan, dosen menanamkan prinsip } \\
\text { kemandirian merupakan kunci penting dalam suatu usaha. }\end{array}$ & 3 & 3,33 & 24 & 26,67 & 41 & 45,56 & 18 & 20,00 & 4 & 4,44 & 3,02 & 60,4 & BAIK \\
\hline 8 & $\begin{array}{l}\text { Dalam pembelajaran kewirausahaan, dosen menanamkan prinsip } \\
\text { kemandirian merupakan suatu keh arusan dalam berusaha. }\end{array}$ & 3 & 3,33 & 26 & 28,89 & 41 & 45,56 & 16 & 17,78 & 4 & 4,44 & 3,06 & 61,2 & BAIK \\
\hline 9 & $\begin{array}{l}\text { Dalam pembelajaran kewirausahaan, dosen menyakinkan bekerja keras } \\
\text { merupak an kunci kesuksesan. }\end{array}$ & 0 & 0,00 & 24 & 26,67 & 33 & 36,67 & 25 & 27,78 & 8 & 8,89 & 2,79 & 55,8 & CUKUP \\
\hline 10 & $\begin{array}{l}\text { Dalam pembelajaran kewirausahaan, dosen meyakinkan jangan cepat puas } \\
\text { dengan hasil yang didap atkan. }\end{array}$ & 10 & 11,11 & 24 & 26,67 & 16 & 17,78 & 26 & 28,89 & 14 & 15,56 & 2,86 & 57,2 & CUKUP \\
\hline 11 & $\begin{array}{l}\text { Dalam pembelajaran kewirausahaan, dosen menanamkan sikap bek erja } \\
\text { terencana, gigh, tabah, dan percaya din. }\end{array}$ & 5 & 5,56 & 24 & 26,67 & 34 & 37,78 & 13 & 14,44 & 14 & 15,56 & 2,89 & 57,8 & CUKUP \\
\hline & & & & & & & & & & & & 2,94 & 58,83 & CUKUP \\
\hline
\end{tabular}

Source: Primary Data on 2014.

Table 6 shows that the patient, diligent and consistent characters consist of 11 item with 90 students as respondent. The average score of item; the lecturer encouraging students to think critically in doing their business is 2.89 with TCR $57.8 \%$ and categorized as adequate. In conclusion, the students of STKIP PGRI Sumatera Barat have low patience, diligence and consistence in managing or doing their business. Therefore, those characteristics need to be cultivated and improved by practicing directly.

\section{g. Ambitious}

The average score of ambitious as the character of entrepreneurship is in very good category; $4.11 \%$ with TCR $82.25 \%$. This character had been implemented during teaching and learning process.

Table 7. The Respondent Distribution Data in Implementing Ambitious

\begin{tabular}{|c|c|c|c|c|c|c|c|c|c|c|c|c|c|c|}
\hline \multicolumn{15}{|c|}{ Ambisi } \\
\hline & & & & & & & HAN & & & & & Skor & TCR & \multirow[t]{3}{*}{ Kriteria } \\
\hline \multirow[t]{2}{*}{ NO } & \multirow[t]{2}{*}{ Pernyataan } & \multicolumn{2}{|c|}{ Selalu } & \multicolumn{2}{|c|}{ Sering } & \multicolumn{2}{|c|}{ Jarang } & \multicolumn{2}{|c|}{ Kadang-kadang } & \multicolumn{2}{|c|}{ Tidak Pernah } & \multirow[t]{2}{*}{ Rata-rata } & & \\
\hline & & $\mathrm{f}$ & $\%$ & f & $\%$ & f & $\%$ & $\mathrm{f}$ & $\%$ & f & $\%$ & & & \\
\hline 1 & $\begin{array}{l}\text { Dalam pembelajaran kewirausahaan, dosen mengembangkan keterampilan } \\
\text { dalam mengatur waktu. }\end{array}$ & 17 & 18,89 & 41 & 45,56 & 26 & 28,89 & 4 & 4,44 & 2 & 2,22 & 3,72 & 74,4 & BAIK \\
\hline 2 & $\begin{array}{l}\text { Dalam pembelajaran kewirausahaan, dosen mem berikan pen getahuan dal am } \\
\text { menjalani usaha. }\end{array}$ & 42 & 46,67 & 39 & 43,33 & 8 & 8,89 & 1 & 1,11 & 0 & 0,00 & 4,34 & 86,8 & Sangat Baik \\
\hline 3 & $\begin{array}{l}\text { Dalam pembelajaran kewirausahaan, dosen berbagi pengalaman ten tang } \\
\text { suatu usaha. }\end{array}$ & 48 & 53,33 & 32 & 35,56 & 8 & 8,89 & 2 & 2,22 & 0 & 0,00 & 4,38 & 87,6 & Sangat Baik \\
\hline 4 & $\begin{array}{l}\text { Dalam pembelajaran kewirausahaan, dosen menanamkan kebiasaan bekerja } \\
\text { keras tidak kenal lelah untuk keberhasilan usaha. }\end{array}$ & 35 & 38,89 & 35 & 38,89 & 12 & 13,33 & 4 & 4,44 & 4 & 4,44 & 4,01 & 80,2 & BAIK \\
\hline & & & & & & & & & & & & 4,11 & 82,25 & Sangat Baik \\
\hline
\end{tabular}

Source: Primary Data on 2014 
The table shows that the ambitious character relatively high in item developing the skill in managing the time with average score 3.72 and TCR $74.4 \%$ and categorized as good. In item providing the knowledge in conducting the business, the average score is 4.34 with TCR $86.8 \%$ and categorized as very good. The average score for item sharing the experience is 4.38 and TCR $87.6 \%$ with very good category. The average score for encouraging hard working to achieve successful in business is 4.01 and TCR $80.2 \%$ with good category. Since the average score for ambitious character is relatively high, it indicates that the students of STKIP PGRI Sumatera Barat are ambitious. Therefore this character should be asserted in learning entrepreneurship.

\section{h. Uneasy to Give Up}

The implementation of uneasy to give up as one of the characters of entrepreneur is categorized as good with average score $36.79 \%$ and TCR $73.58 \%$. This character is necessary in managing the business so that the entrepreneur will be able to survive in high competitive entrepreneurship world.

Table 8. The Respondent Distribution Data in Implementing Uneasy to Give Up

\begin{tabular}{|c|c|c|c|c|c|c|c|c|c|c|c|c|c|c|}
\hline \multicolumn{15}{|c|}{ Pantang Menyerah } \\
\hline \multirow{3}{*}{ NO } & \multirow{3}{*}{ Pernyataan } & \multicolumn{10}{|c|}{ PILIHAN } & \multirow{3}{*}{$\begin{array}{l}\text { Skor } \\
\text { Rata-rata }\end{array}$} & \multirow[t]{3}{*}{ TCR } & \multirow[t]{3}{*}{ Kriteria } \\
\hline & & \multicolumn{2}{|c|}{ Selalu } & \multicolumn{2}{|c|}{ Sering } & \multicolumn{2}{|c|}{ Jarang } & \multicolumn{2}{|c|}{ Kadang-kadang } & \multicolumn{2}{|c|}{ Tidak Pernah } & & & \\
\hline & & $f$ & $\%$ & $f$ & $\%$ & $\mathrm{f}$ & $\%$ & $\mathrm{f}$ & $\%$ & $\mathrm{f}$ & $\%$ & & & \\
\hline 2 & $\begin{array}{l}\text { Dalam pembelajaran kewirausahaan, dosen membiasakan bekerja keras } \\
\text { dalam membangun usahanya }\end{array}$ & 30 & 33,33 & 36 & 40,00 & 18 & 20,00 & 4 & 4,44 & 2 & 2,22 & 3,96 & 79,2 & BAIK \\
\hline 3 & $\begin{array}{l}\text { Dalam pembelajaran kewirausahaan, dosen menanamkan prinsip tidak kenal } \\
\text { lelah dalam membangun usaha. }\end{array}$ & 30 & 33,33 & 48 & 53,33 & 9 & 10,00 & 3 & 3,33 & 0 & 0,00 & 4,15 & 83 & Sangat Baik \\
\hline 5 & $\begin{array}{l}\text { Dalam pembelajaran kewirausahaan, dosen menekankan segera ambil } \\
\text { keputus an untuk mengejar impian. }\end{array}$ & 31 & 34,44 & 37 & 41,11 & 15 & 16,67 & 6 & 6,67 & 1 & 1,11 & 4,04 & 80,8 & Sangat Baik \\
\hline 6 & $\begin{array}{l}\text { Dalam pembelajaran kewirausahaan, dosen meyakinkan sesuatu yang ada } \\
\text { dalam diri kita lebih besar dari pada situasi yang sedang mengungkung kita. }\end{array}$ & 26 & 28,89 & 40 & 44,44 & 13 & 14,44 & 10 & 11,11 & 1 & 1,11 & 3,91 & 78,2 & BAIK \\
\hline 7 & $\begin{array}{l}\text { Dalam pembelajaran kewirausahaan, dosen meyakinkan bahwa setiap } \\
\text { kesuksesan yang pemah kita miliki adalah has il dari keberanian untuk terus } \\
\text { bertah an. }\end{array}$ & 30 & 33,33 & 36 & 40,00 & 18 & 20,00 & 4 & 4,44 & 2 & 2,22 & 3,96 & 79,2 & BAIK \\
\hline 8 & $\begin{array}{l}\text { Dalam pembelajaran kewirausahaan, dosen meyakinkan kesukses an } \\
\text { tergant ung pada apa yang lakukan dengan bakat yang kita miliki. }\end{array}$ & 1 & 1,11 & 29 & 32,22 & 47 & 52,22 & 13 & 14,44 & 0 & 0,00 & 3,17 & 63,4 & BAIK \\
\hline 9 & $\begin{array}{l}\text { Dalam pembelajaran kewirausa haan, dosen meyakinkan orang su kses } \\
\text { menyukai pertempuran dan tantangan. }\end{array}$ & 0 & 0 & 21 & 23,33 & 45 & 50 & 18 & 20 & 6 & 6,67 & 2,89 & 57,8 & CUKUP \\
\hline \multirow[t]{2}{*}{10} & $\begin{array}{l}\text { Dalam pembelajaran kewi rausahaan, dosen menekankan kita mel akukan apa } \\
\text { saja yang memang haru s dilakukan sepanjang waktu apabila itu memang } \\
\text { diperlukan untuk meraih sukses. }\end{array}$ & 17 & 18,89 & 41 & 45,56 & 26 & 28,89 & 4 & 4,44 & 2 & 2,22 & 3,72 & 74,4 & BAIK \\
\hline & & & & & & & & & & & & 3,67 & 73,58 & BAIK \\
\hline
\end{tabular}

Source: Primary Data on 2014

The table shows that the average score of uneasy to give up character is relatively good for students of STKIP PGRI Sumatera Barat. Therefore, it should be asserted and improved in teaching learning process of entrepreneurship subject by applying constructive approach.

\section{i. Honest}

The Honesty character is in adequate category with average score $3.00 \%$ and TCR $60.00 \%$. Entrepreneurship should be conducted with honesty to develop, build up and keep the business in a long term.

Table 9. The respondent Distribution Data of Honest Character

\begin{tabular}{|c|c|c|c|c|c|c|c|c|c|c|c|c|c|c|}
\hline \multirow{3}{*}{ NO } & \multirow{3}{*}{ Pernyataan } & \multicolumn{10}{|c|}{ PLLIHAN } & \multirow{3}{*}{$\begin{array}{l}\text { Skor } \\
\text { Rata-rata } \\
\end{array}$} & \multirow[t]{3}{*}{ TCR } & \multirow[t]{3}{*}{ Kriteria } \\
\hline & & \multicolumn{2}{|c|}{ Selalu } & \multicolumn{2}{|c|}{ Sering } & \multicolumn{2}{|c|}{ Jarang } & \multicolumn{2}{|c|}{ Kadang-kadang } & \multicolumn{2}{|c|}{ Tidak Pernah } & & & \\
\hline & & $\mathrm{f}$ & $\%$ & $\mathrm{f}$ & $\%$ & $\mathrm{f}$ & $\%$ & $\mathrm{f}$ & $\%$ & $\mathrm{f}$ & $\%$ & & & \\
\hline 1 & $\begin{array}{l}\text { Dalam pembelajaran kewirausahaan, dosen menanamkan sikap bahwa modal } \\
\text { besar buk an kebutuhan utama. }\end{array}$ & 1 & 1,11 & 29 & 32,22 & 47 & 52,22 & 13 & 14,44 & 0 & 0,00 & 3,17 & 63,4 & BAIK \\
\hline 2 & $\begin{array}{l}\text { Dalam pembelajaran kewirausahaan, dosen menentukan aspek utama dalam } \\
\text { usaha. }\end{array}$ & 0 & 0,00 & 18 & 20,00 & 55 & 61,11 & 17 & 18,89 & 0 & 0,00 & 3 & 60 & CUKUP \\
\hline 3 & $\begin{array}{l}\text { Dalam pembelajaran kewirausahaan, dosen mengingatkan jangan } \\
\text { mengeluarkan modal yang banyak diawal usaha. }\end{array}$ & 1 & 1,11 & 20 & 22,22 & 44 & 48,89 & 15 & 16,67 & 10 & 11,11 & 2,83 & 56,6 & CUKUP \\
\hline & & & & & & & & & & & & 3 & 60 & CUKUP \\
\hline
\end{tabular}

Source: Primary Data on 2014

The table shows that the honesty character of the students of STKIPPGRI Sumatera Barat need to be improved by keep honest in accounting and managing the business. The constructive approach or direct experience should be implemented to encourage students to be honest to the customer. 


\section{j. Environment Carefree}

The character of environment carefree is in adequate category with the average score $2.99 \%$ and TCR $59.8 \%$. It indicates that the students should give more attention to environment because entrepreneur world need the people who are care with the environment, customer and other consumer. It is needed especially in expanding the business and building up the networking system.

Table 10. The Respondent Distribution Data in Implementing Honesty

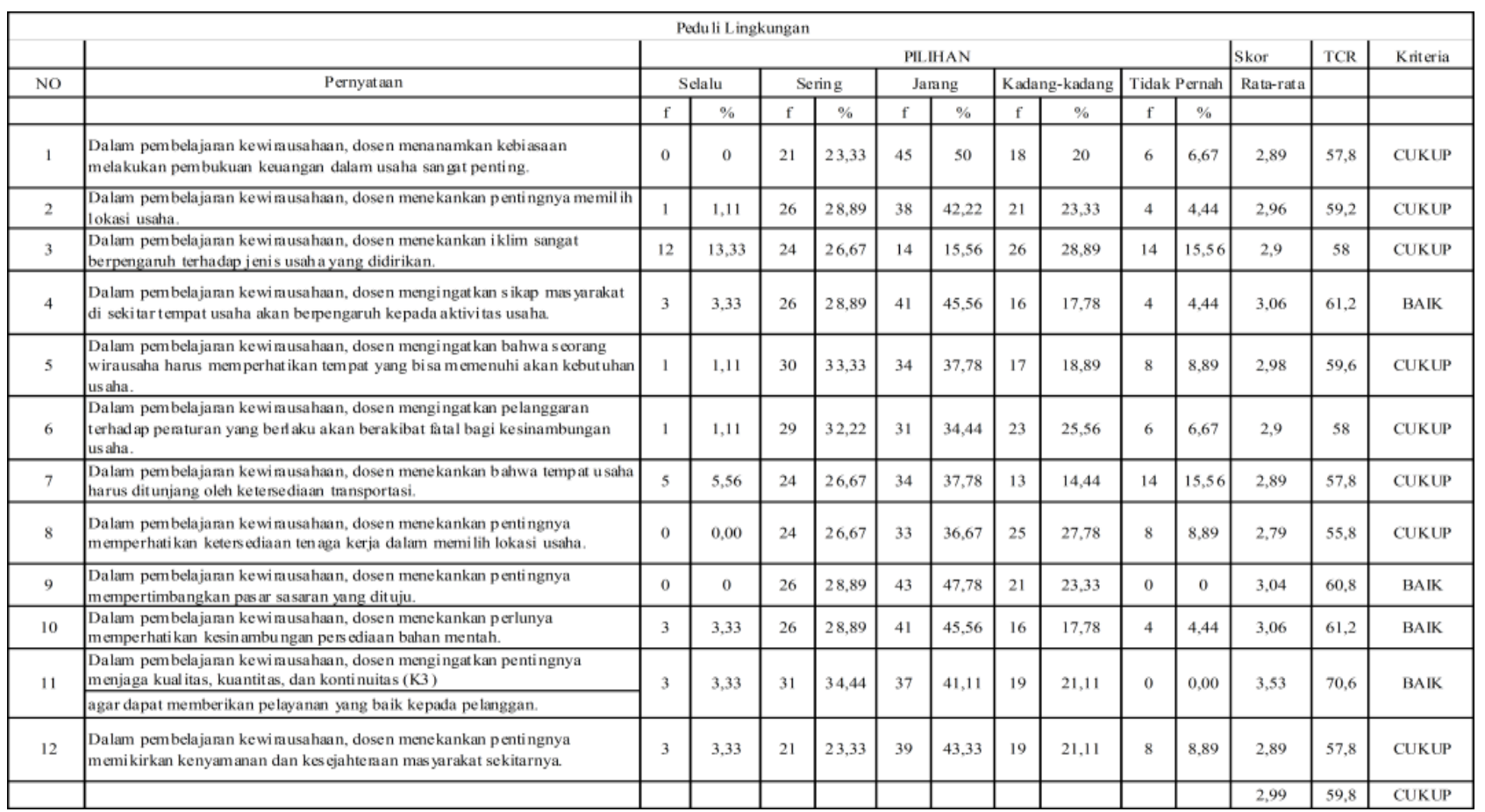

Source: Primary Data on 2014

Since the data shows that the average score for honesty is considered adequate, thus it can be conclude that this character needs to be improved and managed immediately. it also shows that the students of STKIP PGRI Sumatera Barat do not give proper attention to the environment. Meanwhile, in entrepreneurship the people should care with their environment otherwise the business will not run well.

\section{k. Sensitive to the Market Demand}

The average score of the sensitivity to the market demand character is $3.00 \%$ with TCR $60.05 \%$ or in adequate category which means the students' sensitivity to the market demand need to be improved. The business will develop and is able to compete in global market if the people practice their sensitiveness.

Table 11. The Respondent Distribution Data in Implementing Sensitivity to Market Demand

\begin{tabular}{|c|c|c|c|c|c|c|c|c|c|c|c|c|c|c|}
\hline \multicolumn{15}{|c|}{ Peka Terhadap Pasar } \\
\hline \multirow{3}{*}{ NO } & \multirow{3}{*}{ Pernyattaan } & \multicolumn{10}{|c|}{ PILIHAN } & \multirow{3}{*}{\begin{tabular}{|l|} 
Skor \\
Rata-rata \\
\end{tabular}} & \multirow[t]{3}{*}{ TCR } & \multirow[t]{3}{*}{ Kriteria } \\
\hline & & \multicolumn{2}{|c|}{ Selalu } & \multicolumn{2}{|c|}{ Sering } & \multicolumn{2}{|c|}{ Jarang } & \multicolumn{2}{|c|}{ Kadang-kadang } & \multicolumn{2}{|c|}{ Tidak Pernah } & & & \\
\hline & & $\mathrm{f}$ & $\%$ & $\mathrm{f}$ & $\%$ & $\mathrm{f}$ & $\%$ & $\mathrm{f}$ & $\%$ & f & $\%$ & & & \\
\hline 1 & $\begin{array}{l}\text { Dalam pembelajaran kewirausahaan, dosen mengembangkan keterampilan } \\
\text { dalam mengatur keuangan us aha. }\end{array}$ & 0 & 0 & 42 & 46,67 & 31 & 34,44 & 13 & 14,44 & 4 & 4,44 & 3,21 & 64,2 & BAIK \\
\hline 2 & $\begin{array}{l}\text { Dalam pembelajaran kewirausahaan, dosen mengingatkan jangan memulai } \\
\text { suatu program perluasan usaha sebelum siap. }\end{array}$ & 1 & 1,11 & 23 & 25,56 & 47 & 52,22 & 14 & 15,56 & 5 & 5,56 & 2,99 & 59,8 & CUKUP \\
\hline 3 & $\begin{array}{l}\text { Dalam pembelajaran kewirausahaan, dosen memberikan keterampilan dalam } \\
\text { menguasai informasi. }\end{array}$ & 0 & 0 & 19 & 21,11 & 30 & 33,33 & 31 & 34,44 & 10 & 11,11 & 2,63 & 52,6 & CUKUP \\
\hline 4 & $\begin{array}{l}\text { Dalam pembelajaran kewirausahaan, dosen mengembangkan kemampuan } \\
\text { un tuk mengimplementasikan mimpi mereka. }\end{array}$ & 0 & 0 & 43 & 47,78 & 28 & 31,11 & 13 & 14,44 & 6 & 6,67 & 3,18 & 63,6 & BAIK \\
\hline & & & & & & & & & & & & 3,0025 & 60,05 & CUKUP \\
\hline
\end{tabular}

Source: Primary Data on 2014

It can be concluded that the sensitive to the market demand is relatively adequate which needs to be improved. It shows that the students of STKIP PGRI Sumatera Barat are not really sensitive with the market which actually can be improved 
through the constructive approach. This approach gives an opportunity to the students cultivate their sensitivity by observing what the goods or product that easily sold out in the market.

\section{Entrepreneurship with Ethical Standard}

The implementation of this entrepreneurship character is relatively good with average score $4.012 \%$ and TCR $80.24 \%$. The ethical standard in managing the business is very necessary to develop and to achieve successfulness in business.

Table 12. The Respondent Distribution Data in Implementing Ethical Standard Business

\begin{tabular}{|c|c|c|c|c|c|c|c|c|c|c|c|c|c|c|}
\hline \multicolumn{15}{|c|}{ Berbisnis dg Standar Etika } \\
\hline \multirow{3}{*}{ NO } & \multirow{3}{*}{ Pernyataan } & \multicolumn{10}{|c|}{ PILIHAN } & \multirow{3}{*}{\begin{tabular}{|l|} 
Skor \\
Rata-rata \\
\end{tabular}} & \multirow[t]{3}{*}{ TCR } & \multirow[t]{3}{*}{ Kriteria } \\
\hline & & \multicolumn{2}{|c|}{ Selalu } & \multicolumn{2}{|c|}{ Sering } & \multicolumn{2}{|c|}{ Jarang } & \multicolumn{2}{|c|}{ Kadang-kadang } & \multicolumn{2}{|c|}{ Tidak Pernah } & & & \\
\hline & & $\mathrm{f}$ & $\%$ & $\mathrm{f}$ & $\%$ & f & $\%$ & $\mathrm{f}$ & $\%$ & $\mathrm{f}$ & $\%$ & & & \\
\hline 1 & $\begin{array}{l}\text { Dalam pembelajaran kewirausahaan, dosen mengembangkan keterampilan } \\
\text { memilih lokasi us aha. }\end{array}$ & 31 & 34,44 & 37 & 41,11 & 15 & 16,67 & 6 & 6,67 & 1 & 1,11 & 4,04 & 80,8 & Sangat Baik \\
\hline 2 & $\begin{array}{l}\text { Dalam pembelajaran kewirausahaan, dosen memberikan pemahaman } \\
\text { penggunaan keuangan. }\end{array}$ & 26 & 28,89 & 40 & 44,44 & 13 & 14,44 & 10 & 11,11 & 1 & 1,11 & 3,91 & 78,2 & BAIK \\
\hline 3 & $\begin{array}{l}\text { Dalam pembelajaran kewirausahaan, dosen memberikan pemahaman } \\
\text { pengendalian us aha. }\end{array}$ & 30 & 33,33 & 36 & 40,00 & 18 & 20,00 & 4 & 4,44 & 2 & 2,22 & 3,96 & 79,2 & BAIK \\
\hline 4 & $\begin{array}{l}\text { Dalam pembelajaran kewirausahaan, dosen memberikan pen getahuan ten tang } \\
\text { menyusun rencana u saha. }\end{array}$ & 30 & 33,33 & 48 & 53,33 & 9 & 10,00 & 3 & 3,33 & 0 & 0,00 & 4,15 & 83 & Sangat Baik \\
\hline 5 & $\begin{array}{l}\text { Dalam pembelajaran kewirausahaan, dosen membentuk sikap dalam } \\
\text { mewujudkan mi mpi mahasiswa untuk menjalani suatu usaha. }\end{array}$ & 25 & 27,78 & 43 & 47,78 & 18 & 20,00 & 3 & 3,33 & 1 & 1,11 & 4 & 80 & BAIK \\
\hline & & & & & & & & & & & & 4,012 & 80,24 & BAIK \\
\hline
\end{tabular}

Source: Primary Data on 2014

The table shows that the average score in conducting the business with ethical standard is in good category. In other words, the students of STKIP PGRI Sumatera Barat are managing and doing their business based on ethical standard business. However, this character still need to be improved that the students have knowledge in managing their business based on the ethical standard business.

\section{m. Independent}

The average score of implementing the independent character is 3.41 with TCR $68.3 \%$ and is categorized as good. The independent character is necessary in developing the business therefore; it should be improved in learning entrepreneurship. 
Table 13. The Respondent Distribution Data in Implementing Independent Character

\begin{tabular}{|c|c|c|c|c|c|c|c|c|c|c|c|c|c|c|}
\hline \multirow{3}{*}{ No } & \multirow{3}{*}{ Statement } & \multicolumn{10}{|c|}{ Response } & \multirow{3}{*}{$\begin{array}{l}\text { Average } \\
\text { Score }\end{array}$} & \multirow{3}{*}{ TCR } & \multirow{3}{*}{ Criteria } \\
\hline & & \multicolumn{2}{|c|}{ Always } & \multicolumn{2}{|c|}{ Often } & \multicolumn{2}{|c|}{ Seldom } & \multicolumn{2}{|c|}{ Sometime } & \multicolumn{2}{|c|}{ Never } & & & \\
\hline & & $\mathrm{F}$ & $\%$ & $\mathrm{~F}$ & $\%$ & $\mathrm{~F}$ & $\%$ & $\mathrm{~F}$ & $\%$ & $\mathrm{~F}$ & $\%$ & & & \\
\hline 1 & $\begin{array}{l}\text { In } \\
\text { entrepreneurship } \\
\text { learning, the } \\
\text { lecturer builds } \\
\text { students' attitude } \\
\text { of take a } \\
\text { responsibility to } \\
\text { the business that } \\
\text { they have made. }\end{array}$ & 1 & 1,11 & 29 & 32,22 & 47 & 52,22 & 13 & 14,44 & 0 & 0,00 & 3,17 & 63,4 & Good \\
\hline 2 & $\begin{array}{c}\text { In } \\
\text { entrepreneurship } \\
\text { learning, the } \\
\text { lecturer } \\
\text { motivates } \\
\text { students to be an } \\
\text { independent } \\
\text { businessman. }\end{array}$ & 22 & 24,44 & 41 & 45,56 & 19 & 21,11 & 7 & 7,78 & 1 & 1,11 & 3,87 & 77,4 & Good \\
\hline 3 & $\begin{array}{c}\text { In } \\
\text { entrepreneurship } \\
\text { learning, the } \\
\text { lecturer builds } \\
\text { students' } \\
\text { confidence in } \\
\text { doing their own } \\
\text { business } \\
\text { accounting. }\end{array}$ & 35 & 38,89 & 35 & 38,89 & 12 & 13,33 & 4 & 4,44 & 4 & 4,44 & 4,01 & 80,2 & Good \\
\hline 4 & $\begin{array}{c}\text { In } \\
\text { entrepreneurship } \\
\text { learning, the } \\
\text { lecturer } \\
\text { motivates } \\
\text { students to solve } \\
\text { their own } \\
\text { problem as the } \\
\text { businessman. }\end{array}$ & 3 & 3,33 & 26 & 28,89 & 41 & 45,56 & 16 & 17,78 & 4 & 4,44 & 3,06 & 61,2 & Good \\
\hline 5 & $\begin{array}{c}\text { In } \\
\text { entrepreneurship } \\
\text { learning, the } \\
\text { lecturer } \\
\text { emphasizes that } \\
\text { the } \\
\text { businessmanDala } \\
\text { m pembelajaran } \\
\text { kewirausahaan, } \\
\text { dosen } \\
\text { meyakinkan } \\
\text { usahawan harus } \\
\text { bisa bertahan } \\
\text { dalam berbagai } \\
\text { keadaan. } \\
\end{array}$ & 1 & 1,11 & 30 & 33,33 & 34 & 37,78 & 17 & 18,89 & 8 & 8,89 & 2,98 & 59,6 & Adequate \\
\hline & Average & & & & & & & & & & & 3,41 & 68,36 & Good \\
\hline
\end{tabular}

maryData on 2014

The table shows that the students of STKIP PGRISumatera Barat have independent character which is categorized as good and should be improved to gain the success in entrepreneurship.
The research finding on students' entrepreneurship character, 13 items can be classified into three categories; very good group (82.14) consists of enthusiastic and ambitious, good (76.33) consists of dare to take an action, 
uneasy to give up, and ethical standard business, and adequate group(59.13) consists of 7 items; resistant to fear of failure, creative and innovative, optimistic, patient, diligent, and consistent, honest, carefree environment, and sensitive to the market demand. Those data were taken from students by giving the questionnaire while from the lecturer by having an interview. The lecturer admitted that the character of entrepreneurship learning has been implemented in teaching and learning process. The first respondent (ND1) in December 2013 stated that the optimistic character was a key to the successfulness in entrepreneurship. The second respondent (ND2) stated that in the dare to take an action character, the students had it but only in doing paper assignment.

The first respondent (ND1) also stated that the students are not really patient, diligent and consistent in everything. They tend to get the better result in advance without proper effort. Meanwhile, successfulness in entrepreneurship is gained through the process of winning and losing. He also stated that when students fail in doing their business, rather than evaluating and finding the cause of failure, they change their business immediately. In accordance with ND1, the second respondent (ND2) stated that in learning entrepreneurship the students learnt not to give up easily but they would do it if they like otherwise they would give up easily.

In honesty character, ND1 explained that the students were encourage to be honest in doing their business especially in accounting and recording their business. ND2 stated that in the class the students were sensitive to the market demand but had not put their idea into the actual action. The data from both respondents are quite similar in most of the characters of entrepreneurship. In general, the students have the characters of entrepreneur theoretically but not in practically.

\subsection{Discussion}

The implementation of entrepreneurship learning in STKIP PGRI Sumatera Barat is mainly in theoretical rather than practical concept. It indicated by the result of 13 characteristics of entrepreneurship learning that two characteristics are in very good category (enthusiastic and ambitious), four characteristics are classified as good (dare to take an action, uneasy to give up, ethical standard business and independent) and seven characteristics are classified as adequate (resistant to fear of failure, creative and innovative, optimistic, patient, diligent and consistent, honest, carefree environment and he/she sensitive to the market demand).

Research finding shows that the entrepreneur learning in STKIP PGRI SUMBAR has not yet create even stimulate students' entrepreneurial spirit. Even though the students have creative and innovative idea but it is just in their imagination or they have not yet make a realization of what they think into the their business. It is because their ideas were only presented in the classroom in theoretical basis and have never been applied in a real life or outside the classroom. It was supported by the fact that the syllabus is mainly discuss the theoretical concept rather than encourage students to actually practice what they learnt by creating their own business.

The observation showed that the students mainly study in the classroom planning their business rather than directly create and manage their own business. Therefore, they are really good in doing the business on a paper rather than in real life. It is not related to Kimble $(1961,6)$ definition of learning, that learning is relatively permanent change in the potential behavioral that occurs as a result of the practice reinforced. It is clear that the learning outcome is more satisfied if it is strengthened by field practice.

One of the elements that have big contribution to the quality of learning is lecturer, therefore as the main actor he/she should have pedagogic competence. A careful planning will lead the students to do the teaching and learning activities properly and measurable based on the goal or learning target. On the other hand if the planning is designed for administration purpose, then the learning process would depend much on the situation which is faced by both students and lecturer. If the learning situation is conducive, the students would be able to learn otherwise the students will hesitate to learn and the teaching learning process will be done by ignoring the learning principle (Montessori, 2013: 181-182). Therefore, it is very important for the lecturer create a better learning condition and real life study that allow students to create and manage their own business and learn to be an entrepreneur.

The learning obstacles which were faced by students: resistant to fear of failure, creative and innovative, optimistic, patient, diligent, and consistent, honest, carefree environment, and sensitive to the market demand. People can control their fear if they are taught to do it through the experience. The entrepreneurs who have experience in managing their business will face difficulties. However, they will be able to solve even avoid it if they learn and train of how to see the opportunity that drive their creative and innovative thinking to answer the market demand. As stated by Higgin (1995) that innovation can emerge from the skills to analyze the various opportunities that occur.

Achieving successful in business is not without a greater effort because if the entrepreneurs want to get a huge profit, they should be able to take a risk, optimist, and work hard to achieve it. Kasmir (2011) says the greaterthe risk of loss faced by entrepreneur, the greater the profit opportunities he gets. The entrepreneurship learning should be able to create a tough entrepreneur by providing appropriate material and learning strategy. The syllabus should be design with balance portion between theory and practice. Moreover, the teacher should be the one who have knowledge of entrepreneurial knowledge and skill.

\section{Conclusions}

The conclusion for each respondent distribution data can be seen in the table below 
Table 14. RATA-RATA per Item RATA-RATA PER ITEM

\begin{tabular}{|c|c|c|c|c|c|c|c|c|c|c|c|c|}
\hline NO & NAMA ITEM & SKOR RATA-RATA & TCR & KRITERIA & SKOR RATA-RATA & TCR & KRITERIA & SKOR RATA-RATA & TCR & KRITERIA & KURANG BAIK & TIDAK BAIK \\
\hline 1 & PENUH SEMANGAT & 4,1 & 82,04 & SANGAT BAIK & & & & & & & & \\
\hline 2 & AMBISIUS & 4,11 & 82,25 & SANGAT BAIK & & & & & & & & \\
\hline 3 & BERTINDAK & & & & 3,75 & 68,94 & BAIK & & & & & \\
\hline 4 & PANTANG MENYERAH & & & & 3,67 & 73,58 & BAIK & & & & & \\
\hline 5 & BERBISNIS DENGAN STANDAR ETIKA & & & & 4,01 & 80,24 & BAIK & & & & & \\
\hline 6 & MANDIRI & & & & 3,41 & 68,36 & BAIK & & & & & \\
\hline 7 & JANGAN TAKUT GAGAL & & & & & & & 2,97 & 59,5 & CUKUP & & \\
\hline 8 & KREATIF DAN INOVATIF & & & & & & & 3,06 & 60,5 & CUKUP & & \\
\hline 10 & SABAR, ULETDAN TEKUN & & & & & & & 2,94 & 58,83 & CUKUP & & \\
\hline 11 & JUJUR & & & & & & & 3 & 60 & CUKUP & & \\
\hline 12 & PEDULI LINGKUNGAN & & & & & & & 2,99 & 59,8 & CUKUP & & \\
\hline 13 & PEKA TERHADAP PASAR & & & & & & & 3,0025 & 60,05 & CUKUP & 0 & 0 \\
\hline
\end{tabular}

Among 13 items, there are 7 items that should be improved: resistant to fear of failure, creative and innovative, optimistic, patient, diligent, honest, carefree environment and sensitive to the market demand. The strategy that can improve those items in entrepreneurship learning is practicing those items. On the other hand, the items enthusiastic and ambitious need to be strengthened, the other 4 items; dare to take an action, uneasy to give up, ethical standard business and independent should be improved.

\section{REFERENCES}

[1] ADDIE, Braxton, S,. 2006. Instructional Design Model from General Instructional Design

Phases.http://www.futureu.com/publications/braxton/generalp hases. html. diunduhtanggal 15 Januari 2012, pukul 09.00 wib.

[2] Bock. 2001. Getting it Right: R\&D Methods in Science and Engineering. San Fransisco: Jossey Bass.

[3] Damsar. 2005. SosiologiPasar. LaboratoriumSosiologi FISIP Unand: Evektor.

[4] Damsar. 2006. SosiologiUang. Padang: Andalas University Press.

[5] Hannafin, MJ. \& Peck, K.L. 2003. The Design, Development, and Evaluation of Instructional Sofware. New York: McMillan Publishing Company.

[6] Hendro. 2011. Dasar-Dasar Kewirausahaan, Panduanbagi Mahasiswauntuk Mengenal, Memahami, danmemasuki Dunia Bisnis. Jakarta. Eelangga. http://www.ayobukasaja.com/2012/ 06/teori-teori-psikologi-perkembangan.html, diakses tanggal 11 Juni 2013 pukul 22.38 wib. (http://www.dikti.go.id/) diaksestanggal 27 Mei 2013 pukul 20.00 wib.

[7] Joyce, B., Weil, M., dan Emily Calhoun. 2009. Models of Teaching. Boston: Allyn\& Bacon.

[8] Kasmir. 2011. Kewirausahaan. Jakarta. Raja GrafindoPersada. Kompas, Selasa, 30 November 2009.

[9] Nada, Dabbagh\&Brebda Bannan Ridland. 2005. Online
Learning Concepts Strategie. Upper Saddle River NjColombus: Person Merrill Prantice hall.

[10] Miles, Mathew B danHuberman, A. Michael.1992. Analisis Data Kualitatif. PenerjemahTjejepRohendiRohidi. Jakarta: UI Press.

[11] Morison, G.R \& Kemp, J.E. 2001.Designing Effective Instruction. NY: JhonWelwy\& Sons.

[12] Munthe, Bermawi. 2011. Desain Pembelajaran. Yogtakarta: PustakaInsanmadani.

[13] Pribadi, Benny A. 2010. Model DesainSistemPembelajaran. Jakarta: Dian Rakyat.

[14] Robert A. Reiser. 2007. Trend and Issues in Instructional Design and Technology. Upper Saddle River NJ: Pearson Education.

[15] Russel, Smaldino, dkk. 2005. Instructional Technology and Media for Learning. New Jersey: Pearson MerrilPretice Hall inc.

[16] Sagala Syaiful. 2005. Konsepdan Makna Pembelajaran. Bandung: Alfabeta.

[17] Setiadi, Elly M dan Kolip Usman. 2011. Pengantar Sosiologi Pemaham an Faktadan Gejala Permasalahan Sosial: Teori, Aplikasi, dan Pemecahannya. Jakarta: Kencana Prenada Media Group.

[18] Setyosari, Punaji. 2012. Metode Penelitian Pendidikandan Pengembangan. Jakarta: Kencana Prenada Media Group.

[19] Sugiyono, 2011.MetodePenelitianPendidikanPendekatanKuantitatif, Kualitatif, danR\&D. Bandung: Alfabeta.

[20] Suherman, Eman. 2008. DesainPembelajaranKewirausahaan. Bandung: Alfabeta.

[21] Tanako, B. Soleman. 1984. Struktur Dan Proses Sosial Suatu Pengantar Sosiologi Pembangunan. Jakarta: Raja Wali.

[22] Tilaar, H.A.R. 2012.Perubahan Sosialdanpendidikan, Pengantar Pedagogik Transformatifuntuk Indonesia. Jakarta: RinekaCipta.

[23] Trianto, 2010. Pengantar Penelitian Pendidikan Bagi Pengembangan Profesi Pendidikandan Tenaga Kependidikan. Jakarta: Kencana Prenada Media Group.

[24] UU No. 20 Tahun 2003.Tentang Sistem Pendidikan Nasional. 
[25] Walter Dick, Louc Carey. 2005. The Systemic Design of Instruction. Boston: Pearson.

[26] Webmaster.2012. Strategi Perguruan Tinggi Mewujudkan Entrepreneurial Campus. (Online).http://www.dikti.go.id/, diakses 27 Mei 2013 pukul 23.15 wib.
[27] Zimmerer, Thomas W dan Norman M. Scarborough.2005. Pengantar Kewirausahaandan Manajemen Bisnis Kecil (Asli Essentials of Entrepreneurship and Small Business Management).Edisi Keempat. 